\section{AML 06}

SELECTION OF A METASTATIC MASTOCYTOMA P 815 VARIANT AND CHARACTERIZATION OF ITS GANGLIOSIDE PATTERN

G. Bandlow, R. Härtl, K. Ritter, B. Gröner In vitro culturea Mastocytoma P 815 cells were injected into $\mathrm{DBA} / 2$ mice either i.p. or into a tail vain. After intravenious injection tumour cells predominantly proliferated in the liver. The liver was broken up and the released Mastocytoma cells were now transplanted and further passaged i.p. After several passages the volume of tumour ascites gradually decreased whereas the rate of tumour proliferation increased. This selected tumour cell variant could also be differentiated from the original primary gical and electronmicroscopical methods. Both tumour lines differed in vivo in their enzyme pattern in the peripheral blood. The cell surfaces of the two cell lines showed a high content of GSL in the lipid fraction, mainly NANA containing GSL, respectively gangliosides. The gangliosides from Mastocytoma P 815 cells, from liver tissues and from liver infiltrated by tumour cells were analysed by HPTLC. A characteristic pattern was found for liver tissue and Mastocytoma $P$ 815. The infiltrated liver showed a combined pattern of both. Furthermore the pheral blood. Tumour bearing mice showed a higher amount of gangliosides than normal animals. A steady increase of the ganglioside level was observed during tumour growth.

Abtlg. Med. Mikrobiologie, Zentrum für Hygiene und Humangenetik der Universität Göttingen, Kreuzbergring 57, D-3400 Göttingen tumour line using histological, immune histologangliaside content was determined in the peri-

\section{AML 08}

SEQUENTIAL ANTIBIOTIC CHEMOTHERAPY FOR HIGH RISK NEUTROPENIC PATIENTS

C.U.Anders,H.Höfeler, J.Kemper, K. Höffken and C.G.Schmidt

Infections in neutropenic patients are mostly caused by bacteria. Since the responsible pathogens can rarely be identified upon manifestation of the infection, initial antibiotic therapy has to cover a broad bacterial spectrum. Likewise, reqimens for nonresponders to firstline antibiotic therapy should aim at those parts of the spectrum where initial therapy was less effective. We investiqated the seruential antibiotic reaimen described below during 63 febrile episodes in 38 patients.

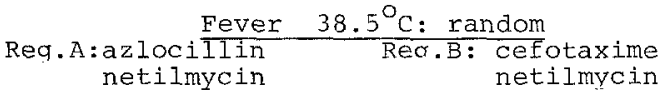
persistent fever for 3 days or relanse Req.C:ceftazidime + netilmycin persistent fever for 3 days or relapse Reg.D:ceftazidime + vancomycin

In conclusion, redimen $A$ and $B$ are equally effective as initial therapy with responserates of $72 \%(A)$ and $70 \%(B)$ respectively. Overall $90 \circ(53 / 59)$ of bacterial infections resoonded to the sequential antibiotic reqimens. The presented antibiotic chemotherapy has demonstrated a high efficacy in neutropenic and immunocompromised patients and diminished mortality of severe infections thus allowing intensified cytostatic therapy with calculable risk.

Innere Universitätsklinik und poliklinik(Tumorforschung), Westdeutsches Tumorzentrum. Hufelandstr.55, D-4300 Essen

AML 09

AML 07

COMPARISON OF CYTOTOXIC EFFECTS OF 1,2,4-TRIGLYCIDYLURAZOI (TGU) ON MURINE HEMATOPOIEIIC PROGENITOR CELLS AND COLONYFORMING LEUREMIC CELLLS (L1210-CFU) IN VIVO

M.R.Nowrousian, C.Doberauer, R.B.Schilcher, C.G.Schmidt

TGU is a new Triepoxide with antitumoral activity in animal models and in man. In the present study, acute and cumulative effects of the agent on hematopoiesis were investigated in mice by measurements of WBC count and marrow concentrations of pluripotential (CFU-S) and granulocytic (CFU-C) progenitor cells. Antileukemic effects were evaluated in a group of mice bearing diffusion chambers (DCs) with $\mathrm{L} 1210$ cells. In these experiments, the activity of TGU was also compared to that of Cyclophosphamide (Cy) and Mafosfamide (Ma), a new Oxazaphosphorine derivative. WBC count and marrow content of $\mathrm{CFU}-\mathrm{S}$ and $\mathrm{CFU}-\mathrm{C}$ were found to be reduced much more severely and to recover less rapidiy after a single dose of $144 \mathrm{mg} / \mathrm{kg}$ than after $36 \mathrm{mg} / \mathrm{kg}$ of TGU. Weekly injections of $36 \mathrm{mg} / \mathrm{kg}$ of TGU for 4 weeks also appeared to be less myelotoxic than the same total dose when given as a single injection. In mice treated with weekly doses of 36,72 (=ID10), 108 or $144 \mathrm{mg} / \mathrm{kg}$ of TGU for 4 weeks, there appeared to be a dose-related but not cumulative suppression of the WBC count and the marrow CFU-S and CFU-C content during the 4 weeks of treatment. After single equitoxic (1/2LD10) doses of TGU ( $36 \mathrm{mg} / \mathrm{kg}$ ), Cy $(200 \mathrm{mg} / \mathrm{kg})$ or Ma $(200 \mathrm{mg} / \mathrm{kg})$, the total number of L1210 cells and the number of L1210-CFU in DCs were found to be reduced to a higher degree by Cy or Ma than by TGU. In al1 3 groups, however, the cells did not recover completeIy during the 21 days of observation. Results indicate doserrelated but not cumulative effects of TGU on hematopoiesis. At equitoxic doses (1/2LD10), TGU seems to have a lower antileukemic effect than Cy or Ma. At this dose level, however, the drug appears to be more toxic to leukemic cells than to normal hematopoietic progenitor cells.

Innere Universitätsklinik und Poliklinik (Thumorforschung), westdeutsches Tumorzentrum, D-4300 Essen Supported by BMFT (PT'B 8223) in Bonn.
THERAPY OF INFECTIONS IN NEUTROPENTC CANCER AND LEUKEMIA PATIENTS WITH TICARCILLIN AND CLAVULANIC ACID

H.H. Fille and K.P. Hellriegel

The main problem in neutropenic patients is prevention and treatment of infections. $55 \mathrm{pa}$ tients suffering from acute leukemias, malignant lymphomas or solide tumours and infections during the granulocytopenic phase were treated with the combination of $5000 \mathrm{mg}$ ticarcillin and $200 \mathrm{mg}$ clavulanic acid given 3 times daily by intravenous short infusion. Immediately after the occurence of fever of more than $38,5^{\circ} \mathrm{C}$ on two consecutive measurements the empiric antibiotic treatment was started. The median granulocyte count was $60 / \mu l$ on the beginning. The clinical and bacteriological examinations documented 13 septicemias, 65 patients the origin of the fever was unknown. Patients were treated for a median duration of 9 days. 30 patients responded to treatment with ticarcillin and clavulanic acid alone. 25 of these patients were cured despite ongoing neutropenia. Patients getting not free of fever received in most instances amikacin, additionally. Thereby, 8 further patients could be cured and 5 patients improved. Thus, 43 of the 53 evaluable patients responded to 4 patients had side effects: 2 diarrhoe, 1 cutaneous rush and 1 anaphylactoid reaction. In conclusion, the combination of ticarcillin and clavulanic acid is a safe and effective treatment for infections in neutropenic cancer patients. For patients not responding, the addition of an aminoglycoside is recommended. II. Innere Abteilung des Krankenhauses Moabit, Turmstr. 21, D-1000 Berl in 21 the empiric antibiotic combination therapy. 